doi: 10.15503.jecs2021.2.77.92

\title{
THE RELATIONSHIP BETWEEN AWARENESS AND BEHAVIOURAL CHANGE IN THE CONTEXT OF THE ISSUE OF VIOLENCE AGAINST WOMEN FROM THE PERSPECTIVE OF DIGITAL PUBLIC RELATIONS AND ONLINE EVENTS
}

\author{
EMEL TOZLU ÖZTAY \\ Istanbul Gelisim University \\ Public Relations and Advertising Department \\ Cihangir, Şehit Jandarma Komando, J. Kom. Er Hakan Öner Sk. No:1 \\ 34310 Avcılar- İstanbul, Türkiye \\ Email address: etozlu@gelisim.edu.tr \\ ORCID: https://orcid.org/0000-0002-8110-2679
}

\begin{abstract}
Aim. The research objective is to implement a scale which has been developed for digital public relations, online events and awareness concepts, on persons who participated in 7 different Webinars themed on women and violence, hence to put forward the power of creating any behavioural change in awareness extent of online events in the scope of digital public relations.

Methods. For this research study, a scale has been devised based on the online event model designed as per digital public relations. In this context, the survey method, one of the quantitative research methods, has been used.

Results. Research findings reveal that the higher online event driven awareness is, the more behavioural changes are in digital public relations; that women, when compared to men, are more responsive to digital public relations applications and have a better level of awareness in comparison; that 18-25 age group is more responsive with a higher level of awareness to digital public relations applications when compared to 26-33 age group; and that parents' educational background makes no difference in this regard.

Conclusions. In light of the research findings, it can be seen that digital public relations applications help to create awareness in terms of online events, and also pave the way for behavioural changes. In this context, it needs highlighting that digital public relations applications should be further improved in particular matters, such as violence against women, in which creating awareness is crucial.
\end{abstract}

Key words: digital public relations, online event management, violence against women, awareness, behavioural change 


\section{INTRODUCTION}

Tn broad terms, we observe an intense effect of digital-online tools on the concept of communication as a consequence of the unavoidable change and transformation of the century we are living in. In consideration of the concept of public relations in this context, the effect of digital-online transformation emerges as an undeniable fact, as in all means of communication. According to We Are Social 2020 report, Internet, social media and mobile user statistics comprise 4.54 billion internet users corresponding to $59 \%$ of world population, 3.80 billion social media users corresponding to $49 \%$ of world population, and 5.19 billion mobile users corresponding to $67 \%$ of world population (We Are Social, 2020). From this aspect, the reason for the ability of individuals and organisations to easily move on, by quickly engaging in digital-online communication during the Covid-19 social isolation period experienced throughout the world and in Turkey, is revealed.

Based on the data in We Are Social 2020 report, it can be suggested that the need for implementation of digital public relations applications is quite important in terms of creating social awareness. In this context, according to Marshall McLuhan, who predicted that digital transformation of the concept of communication would have an impact on social life, every new media tool adds certain social values to and improves individuals, enabling them to adapt to new cultural structures and get shaped according to these new values (McLuhan, 1964). From this aspect, it can be concluded that digital communication may have quite an impact on creating awareness.

Solving problems, addressed by states in terms of public policies, requires legal regulations; however, creating awareness to cause behavioural changes in individuals, manifesting underlying motivations playing a role in decision-making process, providing information, and making use of convincing communication processes are important in terms of the acceptance of policies. (Balta Peltekoglu \& Akbayir, 2019, p. 829)

At this point, it can be suggested that underlining the concept of online event management would be especially important to implement digital public relations applications in the process of creating social awareness.

\section{DIGITAL PUBLIC RELATIONS APPLICATIONS AND AWARENESS}

Filiz Balta Peltekoglu (2018) underlines the concept of public relations as a strategic communication management process; when a large and corporate establishment desires to adapt to the mentality of social responsibility, respond to expectations of its employees, and reach a common ground with mutual communication, two-way symmetrical model is ideal (Balta Peltekoglu, 2018). In parallel with this definition in the context of digital communication, James E. Grunig, who indicates that social media was "a new form of public relations," underlines that social media would "realise the practice of public relations in 
a more global strategic, two-way and interactive manner" (Grunig, 2009, p. 1). According to Grunig, from the aspect of a strategic management paradigm in the context of public relations, it is a very important factor for new digital media to have two-way mutual communication and also interaction (Grunig, 2005).

Grunigand Todd Hunt (1984) indicates that within the scope of two-way symmetrical model, a communication process, which is a mutual feedback with target audiences, is extremely important in public relations. In this context, in implementation of digital public relations events, the use of online networks is extremely important in terms of sharing services provided by the organisation with stakeholders, informing them, and receiving feedback (Gifford, 2010).

While Dmitrii Gavra and Alyona Savitskaya (2012) define digital public relations as applications performed through online media, search engines or social networks, created as communication and interaction channels on online media, Jill Dyche (2002) states that many opportunities to establish two-way communication between consumer and establishments have arisen upon digital implementation of public relations applications, which has made interaction between establishments and their consumers much more quicker and easier. At this point, Janet Gifford remarks that traditional means of public relation were transcended by reaching very wide audiences thanks to the concept of digital public relations (Gifford, 2010). In consideration of digital public relations concept within the scope of available literature, remarks about the concept reveal that the importance of digital public relations concept in processes for creating awareness should be underlined within the new media. In consideration of digital public relations applications (webinar, online congress, conference, etc.) during the social isolation period, it is observed that the participants considered new media as a new public relations environment and adopted such applications quite easily. Grunig, who predicted in 2009 that the environment in question would be formed, remarked that "new media has the potential to make the profession of public relations more global, strategic, two-way and interactive, symmetrical or dialogical, and socially responsible" (Grunig, 2009, p. 1).

According to Çiğdem Kağıtçıbaşı (1999), the concept of awareness is used to indicate the extent, to which people are aware of their attitudes and behaviours. In case of high awareness, before acting, people think about what is right and what is not regarding the situation that they are aware of, and act, i.e. exhibit behaviours, when they consider it to be the right time (Kağıtçıbaşı, 1999). Based on this, it can be suggested that creating awareness with public relations applications could have an impact on behavioural change of the person after the application. At this point, digital public relations emerge as a factor, the need for which should be particularly underlined at the present day.

In the 2030 Agenda of the United Nations, we see the titles improving gender equality and empowerment of women, providing skill changing and employment opportunities for refugees and immigrants, protecting the planet, building risk management and flexibility, preventing severe conflicts and building peaceful communities (Achieving Agenda 2030, 2018). Based on the titles 
in question, implementation of digital public relations applications becomes crucial in creating social awareness and taking action particularly at the present time, as we are going through the social isolation process.

\section{ONLINE EVENT MANAGEMENT}

According to Balta Peltekoglu (2018), the concept of event management, which is extremely important for public relations, defines rituals, presentations, performances, or celebrations, conducted upon planning all details in advance, to serve social, cultural or corporate purposes. In terms of their purposes, events can be categorised as social events, charitable events and corporate events; however, it is possible to diversify these categorisations (Wolf et al., 2005, as cited in Balta Peltekoglu, 2018, p. 325). On the other hand, Johnny Allen, et al., addressed events in terms of their magnitude. In this context, events are addressed under four titles, i.e. local, major, regional and mega events. It is particularly underlined that the most important impact of the hallmark events (hallmark events can also be referred to as milestone or branded events) concerning public relations is creating awareness (Allen et al., 2005, as cited in Balta Peltekoglu, 2018, p. 323).

Improvement of communication technologies and digitalisation of communication affected public relations applications as well, transforming digital communication platforms into alternative communication media for public relations events. At this point, it has become crucial to underline the importance of online events and their effect on awareness. Based on the available literature on the concept, online event management in digital public relations can be defined as a field of application based on creativity, intending to create awareness in lines with objectives and purposes of establishments or organisations. At this point, it should be underlined that one of the most important points in event management is the factor of creativity. It can be suggested that this is extremely important in terms of ensuring memorability of events. An ordinary event can by no means be expected to attract attention, thus creating awareness on the target audience. Particularly at the present time, when technology has been advancing very rapidly, current digital factors in online event management should be pursued and, in this context, creative events should be implemented to create awareness.

In the online event model within the scope of digital public relations (see Fig. 1) set forth in line with online events observed today in the light of available literature, it is prescribed that individuals, establishments and organisations manage online events in four dimensions. These events were categorised as social, cultural, charitable, and corporate. Celebrations may be included in the scope of online social events. Online celebration of holidays on political platforms during the social isolation period due to Covid-19 can be given as an example. Concerts without audiences, which were performed online, can be included in the scope of online cultural events. Online charitable events 
may include events organised on the basis of online fundraising system by various establishments and organisations. On the other hand, online corporate events should be considered in two dimensions. These are events organised for internal target audiences and external target audiences. Events organised for internal target audiences can be exemplified with online personnel motivation events (pilates etc.), while events organised for external target audiences can be exemplified with corporate social responsibility events.

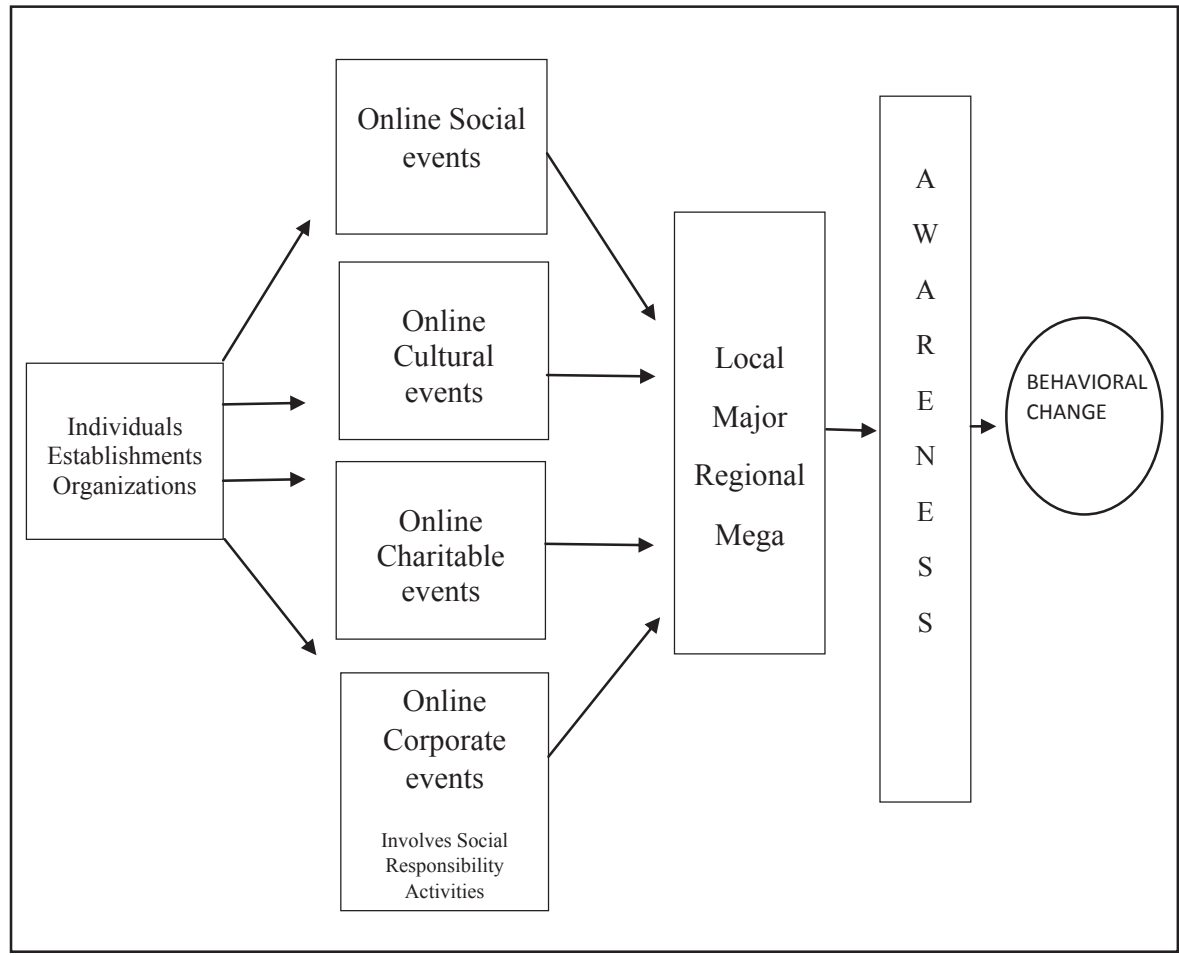

Fig. 1. Online event model within the scope of digital public relations Source: own research

It was asserted that the events performed on four dimensions in the online event model within the scope of digital public relations created in line with the available literature, can be organised as Local, Major, Regional and Mega according to their scopes. However, they cannot be expected to have strict boundaries from an online point of view towards event management. Therefore, in consideration of the speed of online spreading, it should be considered that the event could spread over a wide area by reaching too many people than anticipated in the beginning. Cultural activities involving residents of the area, organised by Istanbul Metropolitan Municipality during the social isolation period, can be given as an example within the scope of the model. An example for online major events could be the online jazz festival 
organised by Istanbul Foundation for Culture and Arts. Others could involve online organisation of International Adana Altin Koza Film Festival as an example of online regional events, and online organisation of the Academy Awards as an example of online mega events. The model contains the factors of awareness, followed by behavioural changes, created by online events. The factors in question were positioned within the model on the basis of available literature and the information that awareness is effective on behavioural change, as set forth by Çiğdem Kağıtçıbaşı (1999). In this regard, it is possible to estimate that there may be a significant relationship between awareness creation and behavioural change aspects of events organised within the scope of digital public relations.

\section{THE ISSUE OF VIOLENCE AGAINST WOMEN}

If addressed in a conceptual aspect, violence can be defined as a fact with multiple variables, which can be encountered in all socio-economic structures. In this context, it is possible to state that violence is directly associated with many factors (such as economic, political, socio-cultural, educational, etc.). "Violence, manifested in personal, interpersonal and collective forms, is, by its nature, addressed under four main titles as physical, sexual, psychological, deprivation and neglect" (World Health Organisation, 2002). Encountering violence under four main titles can be inherently defined as likewise self-propagating factors in violence against women as well. However, it can be said that the most qualitatively measurable aspect is, unfortunately, physical violence. This is because legal implications can be determined in the context of data. Most cases are referred to the judicial system following physical violence; therefore, measurable data is obtained. We encounter such data sometimes as murders committed by men, and sometimes as criminal complaints arising from grievous bodily harm. Violence against women is increasing day by day. As of March, after Covid-19-related social isolation processes started, news regarding violence against women were frequently covered by the media, and 131 femicides and 95 suspicious deaths took place according to the reports by the We Will Stop Femicide Platform, covering the months between April and August 2020. The data reveals the large extent of violence against women during the period in question. At this point, it is necessary to underline the importance of implementing digital public relations applications about creating social awareness. In this context, in consideration of the fact that incidents of violence against women quantitatively increased during the social isolation period, it can be argued that it is extremely important to address the concept from a point of view of online event management in terms of implementing digital public relations applications to create awareness about the issue. 
Table 1

Femicide and suspicious death data from April to August 2020

\begin{tabular}{lcc}
\hline Date Interval & $\begin{array}{c}\text { Femicides } \\
\text { (Committed by } \\
\text { Men) }\end{array}$ & $\begin{array}{c}\text { Suspicious } \\
\text { Deaths of } \\
\text { Women }\end{array}$ \\
\hline 2020 April & 20 & 20 \\
2020 May & 21 & 18 \\
2020 June & 27 & 23 \\
2020 July & 36 & 11 \\
2020 August & 27 & 23 \\
\hline Total & 131 & 95 \\
\hline
\end{tabular}

Source: adapted by the author from 2020 April/ August Reports (http:/ / kadincinayetlerinidurduracagiz.net/kategori/veriler?sayfa=1, Date of Access: 01.09.2020)

\section{PURPOSE OF THE STUDY}

Frequent coverage of news about violence against women in mass media after the beginning of Covid-19-related social isolation process in Turkey reveals the large scale of the issue. In consideration of the data in this context, the data from "We Will Stop Femicide Platform" (non-governmental organisation established to prevent violence against women in Turkey), covering the months between April and August 2020, reveals the importance of implementing digital public relations applications concerning creation of social awareness about violence against women. The purpose of the study is to apply the scale developed within the scope of social responsibility activities towards external target audience, under the title "Online Corporate Events" in the online event model within the scope of digital public relations (see Fig. 1) suggested in line with online events observed at the present day in the light of available literature, on people attending 7 webinars about women and violence, and to set forth the power of online events, within the scope of digital public relations, to create behavioural changes in terms of awareness.

\section{SAMPLE AND METHOD OF THE STUDY}

Sample of the study includes 97 of 150 people in total who attended 7 webinars about women and violence ("Strong Women Working Mothers," "Solidarity at Home During Social Isolation," "Life Fits into Home Unlike Violence," "No to Social Distance in Housework," "Don't be a Bystander," "We are Responsible at Home," "Your Beauty Your Choice"), organised by the Department of Public Relations and Advertising and the Gender Research and Application Center of Istanbul Gelisim University in one hour between the dates May 27, 2020 and June 05, 2020 during the social isolation process. In this context, survey method, one of the quantitative research methods, was used. Obtained data was transferred to Statistical Package for the Social Sciences (SPSS) for Windows 21.0 statistical 
package software and evaluated with this software. A 5-point likert scale, comprising a total of 21 items in 2 aspects, was used. 5 represents completely agree, while 1 represents completely disagree. There was no disqualified survey and no unanswered question. To fulfil reliability-validity criteria, Cronbach Alpha value was used to test reliability of the survey, and Kaiser-Meyer-Olkin statistic was used to test value and validity. Scales within the scope of the study were generally in the range of $0.90<\mathrm{KMO} \leq 0.80^{\prime}$ (general awareness and behavioural change scale value addressed within the scope of the study was 0.896) according to scale validity table of Kaiser-Meyer-Olkin (KMO) Statistic. This indicates that validity of the scale was good. General Cronbach Alpha value of scales, addressed within the scope of the study, was 0.949 . Upon evaluation of the scale reliability coefficient in the study based on general criteria scales, it is observed to be highly reliable. All tests were conducted at 0.05 significance level, which is preferred in social sciences.

Hypotheses developed within the scope of the study are as follows:

H1.There is a significant relationship between the variable of awareness creation by online events and the variable of behavioural change in the context of digital public relations.

H2. There is a significant difference between the variable of awareness creation by online events and the variable of gender in the context of digital public relations. H3. There is a significant relationship between the variable of awareness creation by online events and the variable of age in the context of digital public relations. H4. There is a significant relationship between the variable of awareness creation by online events and the variable of mother's educational background in the context of digital public relations.

H5. There is a significant relationship between the variable of awareness creation by online events and the variable of father's educational background in the context of digital public relations.

\section{FINDINGS}

\section{Demographic Attributes of Study Participants}

Demographic attributes of surveyed workers are indicated in the following table.

Table 2

Distribution of participants by gender

\begin{tabular}{lcc}
\hline Gender & $\begin{array}{c}\text { Number of } \\
\text { participants }\end{array}$ & Percentage \\
\hline Female & 49 & 50.52 \\
Male & 48 & 49.48 \\
\hline Total & 100 & 100 \\
\hline
\end{tabular}

Source: own research

According to the table showing gender distribution of research participants, among 97 people, 49 are women (50.52\%), while 48 are men $(49.48 \%)$. 
Journal of Education Culture and Society No. 2_2021

Table 3

Distribution of participants by age.

\begin{tabular}{lcc}
\hline Age & $\begin{array}{c}\text { Number of } \\
\text { participants }\end{array}$ & Percentage \\
\hline 18 to 25 & 85 & 87.63 \\
26 to 33 & 12 & 12.37 \\
\hline Total & 100 & 100 \\
\hline
\end{tabular}

Source: own research

According to the table showing age distribution of research participants, among 97 people, 85 are in 18 to 25 age interval $(87.63 \%)$, and 12 are in 26 to 33 age interval (13.37\%).

Table 4

Distribution of participants by educational background

\begin{tabular}{lcc}
\hline Educational background & $\begin{array}{c}\text { Number of } \\
\text { participants }\end{array}$ & Percentage \\
\hline University student & 97 & 100 \\
\hline Total & 100 & 100 \\
\hline
\end{tabular}

Source: own research

According to the table showing educational background distribution of research participants, among 97 people, 97 are university students (100\%).

Table 5

Distribution of participants according to mother's educational background

\begin{tabular}{lcc}
\hline Mother's educational background & $\begin{array}{c}\text { Number of } \\
\text { participants }\end{array}$ & Percentage \\
\hline Literate & 1 & 1.03 \\
\hline Primary School & 48 & 49.48 \\
\hline High School & 28 & 28.87 \\
\hline Associate Degree & 3 & 3.09 \\
\hline Bachelor's Degree & 16 & 16.49 \\
\hline Graduate Degree & 1 & 1.03 \\
\hline Total & 100 & 100 \\
\hline
\end{tabular}

Source: own research

According to the table showing mother's educational background distribution of research participants, among 97 people, 1 person's mother is literate, 48 people's mothers are primary school graduates, 28 people's mothers are high school graduates, 3 people's mothers have associate degrees, 16 people's mothers have bachelor's degrees, and 1 person's mother has a graduate degree. 
Table 6

Distribution of participants according to father's educational background

\begin{tabular}{lcc}
\hline Father's educational background & $\begin{array}{c}\text { Number of } \\
\text { participants }\end{array}$ & Percentage \\
\hline Primary School & 40 & 41.24 \\
\hline High School & 34 & 35.05 \\
\hline Associate Degree & 2 & 2.06 \\
\hline Bachelor's Degree & 18 & 18.56 \\
\hline Graduate Degree & 3 & 3.09 \\
\hline Total & 100 & 100 \\
\hline
\end{tabular}

Source: own research

According to the table showing father's educational background distribution of research participants, among 97 people, 40 people's fathers are primary school graduates, 34 people's fathers are high school graduates, 2 people's fathers have associate degrees, 18 people's fathers have bachelor's degrees, and 3 people's fathers have graduate degrees.

Table7

Awareness creation stage frequency analysis results

\begin{tabular}{lc}
\hline Questions & $\begin{array}{c}\text { Frequency } \\
\text { value }\end{array}$ \\
\hline $\begin{array}{l}\text { 1. The online event, which I attended, helped me notice the issue of vio- } \\
\text { lence against women. }\end{array}$ & $4.32 / 5$ \\
\hline $\begin{array}{l}\text { 2. The online event, which I attended, helped me notice that violence } \\
\text { against women was a social issue. }\end{array}$ & $4.68 / 5$ \\
\hline $\begin{array}{l}\text { 3. The online event, which I attended, helped me notice the wide extent of } \\
\text { the issue of violence against women. }\end{array}$ & $4.4 / 5$ \\
\hline $\begin{array}{l}\text { 4. The online event, which I attended, helped me notice that violence } \\
\text { against women existed in different forms in sexual, physical, psychologi- } \\
\text { cal, economic and digital aspects. }\end{array}$ & $4.58 / 5$ \\
\hline $\begin{array}{l}\text { 5. The online event, which I attended, made me think about the impor- } \\
\text { tance of non-governmental organisations regarding the issue of violence } \\
\text { against women. }\end{array}$ & $4.25 / 5$ \\
\hline $\begin{array}{l}\text { 6. The online event, which I attended, made me think about how the issue } \\
\text { of violence against women could be prevented. }\end{array}$ & $4.49 / 5$ \\
\hline $\begin{array}{l}\text { 7. The online event, which I attended, made me think about how aware- } \\
\text { ness could be created regarding the issue of violence against women. }\end{array}$ & $4.36 / 5$ \\
\hline $\begin{array}{l}\text { 8. The online event, which I attended, made me think about how aware- } \\
\text { ness could be created regarding the aspects (sexual, physical, psychologi- } \\
\text { cal, economic and digital aspects) of issue of violence against women. }\end{array}$ & $4.44 / 5$ \\
\hline $\begin{array}{l}\text { 9. After the online event, which I attended, online posts (web news, so- } \\
\text { cial media posts, etc.) of non-governmental organisations (Mor Cati, etc.) } \\
\text { participating in the event, involving the issue of violence against women, } \\
\text { started to attract my attention. }\end{array}$ & $4.3 / 5$ \\
\hline
\end{tabular}


Questions

Frequency

value

10. After the online event, which I attended, online materials (post, eposter, e-brochure, etc.) of non-governmental organisations (Mor Cati, etc.) participating in the event, involving the issue of violence against women, started to attract my attention.

11. After the online event, which I attended, TV materials (TV news, shows, series, etc.) of non-governmental organisations (Mor Cati, etc.) participating in the event, involving the issue of violence against women, started to attract my attention.

12. After the online event, which I attended, art works (motion pictures, music, photograph, painting, etc.) discussed within the scope of the event, involving the issue of violence against women, started to attract my attention.

Total Average 4.37

Source: own research

Table 8

Final behaviour stage frequency analysis results

Questions

Frequency value

13. After the online event, which I attended, I started researching online to support and join NGOs such as Mor Cati, opposing violence against women.

14. After the online event, which I attended, I started researching new online events organised by NGOs such as Mor Cati, opposing violence against women, to attend.

15. After the online event, which I attended, I started researching "no to violence against women" applications mentioned during the event.

16. After the online event, which I attended, I started researching opinion leaders (artist, scientist, etc.) supporting NGOs such as Mor Cati.

17. After the online event, which I attended, I started following social media accounts of NGOs (such as Mor Cati) opposing violence against women.

18. After the online event, which I attended, I started retweeting and commenting on news about violence against women in my social media account.

19. After the online event, which I attended, I joined online to NGOs opposing Violence Against Women.

20. After the online event, which I attended, I started informing people, who I think/know to have suffered from violence, about how to act to solve the issue of violence against women.

21.After the online event, which I attended, I witnessed a person suffering violence against women and acted pursuant to what I learned during the event. (I called relevant numbers, or I e-mailed relevant authorities to report the incident.)

Total Average

Source: own research 
In consideration of the average scores of awareness creation stage frequency analysis results and behavioural change frequency analysis results, it can be suggested that the participants, with 4.37 and 3.92 values, agree with opinions in 21 statements developed within the scope of the scale. Based on such data, it is possible to reach the finding that digital public relations applications have an impact on creating awareness with online events.

Table 9

Results of Pearson Product-Moment Correlation Analysis carried out to determine the relationship between awareness creation variable and behavioural change variable

\begin{tabular}{llcl} 
Awareness Creation Variable & $\mathrm{N}$ & $\mathrm{R}$ & $\mathrm{p}$ \\
\hline Behavioural Change Variable & 97 & 0.611 & 0 \\
\hline
\end{tabular}

Source: own research

According to the results of Pearson Product-Moment Correlation Analysis, it was found that there was a positive and significant relationship between the average score received from awareness creation variable and the average score received from behavioural change variable $(r=0.611 ; p<0.05)$. In this case, H1 is accepted. Based on this, it can be suggested that behavioural change increases as awareness increases.

Table 10

Results of gender-based Mann-Whitney U Difference Test of scores received from awareness creation variable

\begin{tabular}{lccccc} 
Gender & $\mathrm{N}$ & Mean Rank & Rank Sum & $\mathrm{U}$ & $\mathrm{p}$ \\
\hline Female & 49 & 58.14 & 2849.00 & & \\
Male & 48 & 39.67 & 1904.00 & 728 & 0.001
\end{tabular}

Source: own research

According to the results of Mann-Whitney U Difference Analysis, scores of awareness creation variable scale exhibit significant difference according to gender variable $(\mathrm{p}<0.05)$. In this case, $\mathrm{H} 2$ is accepted. It is seen that awareness variable mean rank of women (58.14) is higher than men (39.67). Based on this, it can be suggested that women are affected more by digital public relations applications and have higher awareness than men, according to the scores of awareness creation variable scale. 
Journal of Education Culture and Society No. 2_2021

Table 11

Kruskal Wallis Difference Results by age in test scores received form awareness creation variable

\begin{tabular}{lccccc} 
Age & $\mathrm{N}$ & Mean Rank & sd & $\begin{array}{l}\text { Kruskal- } \\
\text { Wallis H }\end{array}$ & $\mathrm{p}$ \\
\hline $18-25$ & 85 & 52.64 & 1 & 11.681 & 0.001 \\
$26-33$ & 12 & 23.25 & & &
\end{tabular}

Source: own research

According to the results of Kruskal Wallis Difference Analysis, awareness creation variable scores exhibit significant variation than age variable ( $\mathrm{p}<$ 0.05). In this case H3 is accepted. It is seen that awareness variable mean rank of 18-25 age group (52.64) is higher than 26-33 age group (23.25). Based on this, it can be suggested that 18-25 age group is affected more by digital public relations applications and has higher awareness than 26-33 age group, according to the scores of awareness creation variable scale.

Table 12

Kruskal Wallis Difference Test results of scores received from awareness creation variable according to mother's educational background variable

Mother's

Educational

Background

N Mean Rank Sd Kruskal-

Wallis $\mathrm{H}$

$\mathrm{p}$

\begin{tabular}{lccccc}
\hline Literate & 1 & 72.5 & & & \\
Primary School & 48 & 49.99 & & & \\
High School & 28 & 50.13 & 5 & 4.98 & 0.481 \\
Associate Degree & 3 & 54.67 & & & \\
Bachelor's Degree & 16 & 39.06 & & & \\
Graduate Degree & 1 & 88.5 & &
\end{tabular}

Source: own research

Awareness creation variable scale scores do not exhibit significant difference according to mother's educational background variable $(p>0.05)$. In this case, H4 is rejected. Based on this, it can be suggested that awareness affected by digital public relations applications is not associated with mother's educational background variable. 
Table 13

Kruskal Wallis Difference Test results of scores received from awareness creation variable according to father's educational background variable

Father's

Educational

Background

Primary School

40

49.31

High School

34

45.59

Associate Degree

2

28.75

4

2.93

0.570

Bachelor's Degree

55.11

Graduate Degree

3

60.33

Source: own research

Awareness creation variable scale scores do not exhibit significant difference according to father's educational background variable $(p>0.05)$. In this case, H5 is rejected. Based on this, it can be suggested that awareness affected by digital public relations applications is not associated with father's educational background variable.

\section{CONCLUSION AND RECOMMENDATIONS}

Development in communication technologies and digitalisation of communication affected public relations practices as well, converting digital communication platforms into a public relations communication medium. The introduction of digital public relations applications gained prominence, particularly upon the beginning of Covid-19 social isolation process. At this point, the concept of event management, which is a field of application intertwined with public relations, should be underlined. Upon transformation of public relations applications into digital public relations, the concept of event management was thus transformed into the concept of online events. It is a fact that creative online events may increase the awareness creation power of digital public relations. In this context, creative online events are needed within the scope of digital public relations applications to create awareness at the present day. At this point, the foremost issue, for which awareness should be created, is violence against women.

Particularly, violence against women in Turkey is a significant social issue awaiting solution. The reports prepared by the We Will Stop Femicide Platform between April and August 2020 indicate that this issue was complicated even further during the Covid-19 social isolation process. Study results demonstrate that immediate implementation of digital public relations applications to create awareness and organisation of online events within this scope would be a first and important step to solve the issue. 
According to study results, in consideration of the average scores of awareness creation stage frequency analysis results and behavioural change frequency analysis results, it can be suggested that the participants, with 4.37 and 3.92 values, agree with opinions in 21 statements developed within the scope of the scale. Based on such data, it is possible to reach the finding that digital public relations applications have impact on creating awareness with online events. According to the results of Pearson Product-Moment Correlation Analysis, it was found that there was a positive and significant relationship between the average score received from awareness creation variable and the average score received from behavioural change variable $(r=0.611 ; p<0.05)$. In this case, H1 is accepted. Based on this, it can be suggested that behavioural change increases as awareness increases.

According to the results of Mann-Whitney U Difference Analysis, scores of awareness creation variable scale exhibit significant difference according to gender variable $(p<0.05)$. In this case, $\mathrm{H} 2$ is accepted. It is seen that awareness variable mean rank of women (58.14) is higher than men (39.67). Based on this, it can be suggested that women are affected more by digital public relations applications and have higher awareness than men according to the scores of awareness creation variable scale.

According to the results of Kruskal Wallis Difference Analysis, awareness creation variable scores exhibit significant variation than age variable $(p<0.05)$. In this case H3 is accepted. It is seen that awareness variable mean rank of 18-25 age group (52.64) is higher than 26-33 age group (23.25). Based on this, it can be suggested that $18-25$ age group is affected more by digital public relations applications and has higher awareness than 26-33 age group according to the scores of awareness creation variable scale.

The results of the study show that the scores on the awareness formation variable scale do not differ significantly $(p>0.05)$ depending on the mother's education. H4 is rejected in this case. From this perspective, the state of being aware as a result of being affected in digital public relations practices is unrelated to the mother's education variable. The scores of the awareness formation variable did not differ significantly according to the father's education variable ( $p>0.05)$ in another analysis. H5 is rejected in this case. From this perspective, it can be deduced that being aware of being influenced by digital public relations practices has nothing to do with the father's education.

Based on the findings of the study, it is can be observed that digital public relations applications have awareness creating and also behaviour changing effects within the scope of online events. The power of this effect may vary for circumstances such as field of application, time, participants, subject, etc.; however, the presence of the effect is an undeniable fact. In this context, it should be underlined that digital public relations applications should be developed in areas such as violence against women, where it is extremely important to create awareness, during the Covid-19 social isolation process that spread throughout the world and during which we must adapt to a new world system. 


\section{REFERENCES}

[1] Allen, J., O'Toole, W., Harris, R., \& Mcdonnell, I. (2008). Festival and Event Management. New York: John Wiley \& Sons Incorporated Press.

[2] Balta Peltekoğlu, F., \& Akbayır, Z. (2019). Davranışsal İçgörü ve Halkla İlişkilerin Kesişim Noktası: Çocuk Gelin Sorununda Medyada Farkındalık ve Davranışsal Halkla İlişkiler [Intersection of behavioural insights and public relations: Media awaraness of the child bride issue and behavioural public relations]. Erciyes İletişim Dergisi, 6(2), 827-844.

[3] Balta Peltekoğlu, F. (2018). Halkla İliskiler Nedir? [What is Public Relations?]. Istanbul: Beta Press.

[4] Center, A. H., Jackson, P., Smith, S., \& Stansberry, F. R. (2008). Public relations practices: Managerial case studies and problems. USA: Pearson Prentice Hall.

[5] Dyche, J., (2002). The CRM handbook: A business guide to customer relationship management. USA: Addison-Wesley Professional.

[6] Gavra, D. P., \& Savitskaya, A. S. (2012). Digital public relations in the Russian governmental communication: 2011-2012. Typology and General Situation. Journalism and Mass Communication, 2(12), 1127-1138.

[7] Gifford, J. E (2010). Digital public relations: E-Marketing's big secret. Continuing Higher Education Review, 74, 62-72.

[8] Grunig, J. E. (2005). Halkla İlişkiler ve İletişim Yönetiminde Mükemmellik, [Excellence in Public Relations and Communication Management]. James E. Grunig (Ed), Elif Özsayar (Trans.) İstanbul: Rota Press.

[9] Grunig, J. E., \& Hunt, T. T. (1984). Managing public relations. Holt, Rinehart and Winston.

[10] Grunig, J. E. (2009). Paradigms of global public relations in an age of digitalisation. PRism, 6(2), 1-19.

[11] Kağıtçıbaşı, Ç. (1999). Yeni insan ve insanlar [New people and people]. İstanbul: Evrim Press.

[12] Mcluhan, M. (1964), Understanding media: The extensions of man. NY, USA: New American Library.

[13] UNDP: Behavioural Insights at the United Nations Achieving Agenda 2030. (2018). Retrieved May 01, 2020, from https://www.undp.org/content/dam/undp/library/innovation/Behavioural\%20Insights $\% 20$ at $\% 20$ the $\% 20$ UN.pdf.

[14] We Are Social 2020: World Internet, Social Media and Mobile Usage Statistics (2020). Retrieved May 16, 2020, from https:// wearesocial.com/digital-2020.

[15] We Will Stop Femicide Platform: Between April and August Data 2020. (2020). Retrieved September 01, 2020, from http:/ / kadincinayetlerinidurduracagiz.net/kategori/veriler?sayfa=1

[16] Wolf, P., Wolf, J., \& Levine, D. (2005). Event Planning Made Easy, New York: McGraw-Hill. Liite, 1(1), 3 .

[17] World Health Organisation (2002). World report on violence and health: Summary. Retrieved April 02, 2020, from http://www.who.int/violence_injury_prevention/violence/world_report/ en/summary_en.pdf 